\title{
Sperm morphological and morphometric evaluation in captive collared peccaries (Pecari tajacu) ${ }^{1}$
}

\author{
Patrícia C. Sousa ${ }^{2}$, Erika A.A. Santos², Ana L.P. Souza², Gabriela L. Lima², \\ Felipe F.P.C. Barros ${ }^{2}$, Moacir F. Oliveira ${ }^{2}$ and Alexandre R. Silva ${ }^{2 *}$
}

\begin{abstract}
Sousa P.C., Santos E.A.A., Souza A.L.P., Lima G.L., Barros F.F.P.C., Oliveira M.F. \& Silva A.R. 2013. Sperm morphological and morphometric evaluation in captive collared peccaries (Pecari tajacu). Pesquisa Veterinária Brasileira 33(7):924-930. Laboratório de Conservação de Germoplasma Animal, Universidade Federal Rural do Semi-Árido, BR 110 Km 47, Presidente Costa e Silva, Mossoró, RN 59625-900, Brazil. E-mail: legio2000@yahoo.com

The aim of this study was to compare different staining methods for the evaluation of sperm morphology by light microscopy and also to describe the morphometry of the entire sperm in collared peccaries (Pecari tajacu). Semen from 10 males was obtained by electroejaculation and evaluated for sperm motility, vigor, and concentration. Semen smears were prepared through three different staining methods: Bengal rose, brome-phenol blue, and eosin-nigrosin. Smears were evaluated under light microscopy and sperm morphologic alterations were determined in percentage. In addition, sperm morphometric analysis was conducted by light microscopy coupled to image analyzer software. The smears stained with Bengal Rose provide the best results for the visualization of the sperm tail, midpiece, and head. The use of eosin-nigrosin stain did not allow an adequate impregnation, and some sperm presented a few contrasts with the background. A higher incidence of bent coiled tails was verified in the use of brome-phenol blue staining $(\mathrm{P}<0.05)$. Through morphometric evaluation, it was observed that the tail occupies the greatest proportion (89\%) of the sperm which presents a discretely elongated head. According to the results, the use of the Bengal Rose stain is recommended for the morphologic evaluation of the collared peccary sperm.
\end{abstract}

INDEX TERMS: Pecari tajacu, staining, sperm morphology, sperm morphometry.

RESUMO.- [Avaliação morfológica e morfométrica de espermatozoides de catetos (Pecari tajacu).] 0 objetivo deste estudo foi comparar diferentes métodos de coloração para avaliação da morfologia espermática por microscopia de luz e também descrever a morfometria completa de espermatozoides de catetos (Pecari tajacu). Sêmen de 10 machos foi obtido por eletroejaculação e avaliado quanto à motilidade espermática, vigor e concentração. Foram preparados por três diferentes métodos de coloração: Rosa de Bengala, Azul de Bromofenol e Eosina-Nigrosina. Os esfregaços foram avaliados por microscopia de luz, e determinado o percentual das alterações morfológicas. Ainda,

\footnotetext{
${ }^{1}$ Received on December 17, 2012.

Accepted for publication on April 20, 2013.

${ }^{2}$ Laboratório de Conservação de Germoplasma Animal, Universidade Federal Rural do Semi-Árido (Ufersa), BR $110 \mathrm{Km} \mathrm{47,} \mathrm{Presidente}$ Costa e Silva, Mossoró, RN 59625-900, Brazil. *Corresponding author: legio2000@yahoo.com
}

a análise da morfometria espermática foi realizada por microscópio de luz acoplado a um softwere de análise de imagens. Os esfregaços corados com Rosa de Bengala apresentaram melhores resultados de visualização da cauda, peça intermediária e cabeça dos espermatozoides. 0 uso do corante Eosina-Nigrosina não permitiu uma adequada impregnação e alguns dos espermatozoides apresentaram pouco contraste com o fundo da lâmina. Uma maior incidência de cauda fortemente enrolada foi verificada com o uso do corante Azul de Bromofenol $(\mathrm{P}<0.05)$. Através da avaliação morfométrica foi observada que a cauda ocupa a maior proporção (89\%) do espermatozoide, e a cabeça apresenta-se discretamente alongada. De acordo com os resultados, o uso do corante Rosa de Bengala é recomendado para a avaliação morfológica de espermatozoides de catetos.

TERMOS DE INDEXAÇÃO: Pecari tajacu, coloração, morfologia espermática, morfometria espermática. 


\section{INTRODUCTION}

The knowledge on the reproductive aspects of collared peccaries (Pecari tajacu) is of paramount importance to contribute for the development of appropriate management practices for them (Mayor et al. 2007). Several researches have been demonstrating important aspects of their reproduction. The spermatogenesis, that presents a general profile 1:64, is very similar to that in domestic pigs (Costa et al. 2004). The leydigosomatic index is $0.022 \%$, and the number of Leydig cell per testis and per gram of testis is 1.7 billion and 92.12 million, respectively, in this species (Costa et al. 2007). Recently, the spermatogenic cycle and entire spermatogenic process were described as approximately $12.3 \pm 0.2$ and $55.1 \pm 0.7$ days, respectively (Costa et al. 2010). In addition, various studies have reported the general sperm characteristics of collared peccaries collected by electroejaculation (Hellgreen et al. 1989, Costa and Paula 2005, Kahwage et al. 2010). In such studies, values for normal sperm morphology have been varying from 40 (Hellgreen et al. 1989) to 68\% (Kahwage et al. 2010).

The subjective assessment of sperm morphology based on visual observation has led to widely varying results due to numerous factors such as the use of different staining procedures (Hidalgo et al. 2005). The goal of a technique for sperm staining is to ease the visualization of the cells and provide a better identification of the abnormalities through light microscopy (Villaverde et al. 2008). Several staining methods such as the brome-phenol blue (Toniolli et al. 2010), the eosin-nigrosin (Moraes et al. 2010), the diff-quick test (Kim et al. 2011), the Cerovský (Fridrichová et al. 2011), and the Williams-modified (Am-in et al. 2011) are reported for sperm morphology analysis in the swine, that is the domestic species more closely related to the collared peccaries (Cavalcante-Filho et al. 1998). In these last ones, only the eosin-nigrosin (Kahwage et al. 2010) and the Bengal rose (Castelo et al. 2010) staining are described for sperm evaluation, but comparisons among techniques are necessary in order to identify the most suitable for the species.

Understanding the adaptive significance of sperm form and function has been a challenge to biologists, because sperms are highly specialized cells operating at a microscopic level in a complex environment (Gage 1998). The association between sperm function and morphometry, including the size of the head, midpiece, and flagellum, is empirically supported across different species (Immler et al. 2010). In bulls, the use of sperm head morphometric parameters has been considered a good indicator of semen quality (Phillips et al. 2004), and it is recommended as a part of the spermiogram for domestic animals (Rodríguez-Martínez 2007). In collared peccaries, the morphometry of the sperm head was previously described (Meisner et al. 2005), but the dimensions of the other segments as the sperm midpiece and flagellum remain unknown.

The aim of this study was to compare different staining methods for the evaluation of sperm morphology by light microscopy and also to describe the morphometry of the entire sperm in collared peccaries.

\section{MATERIALS AND METHODS}

Experimental protocols and animal care were approved by the ethics committee of Universidade Federal Rural do Semi-Árido, Mossoró (Ufersa), Brazil (Protocol 23091.002802/2011-49). Ten healthy and sexually mature collared peccaries males aged $21 \pm 1$ months and each weighing $20.1 \pm 0.1 \mathrm{~kg}$ were used. The animals belonged to the Centre of Multiplication of Wild Animals (CEMAS/ Ufersa), located in northeast Brazil (Mossoró/RN, Brazil; 5¹0’S, $37^{\circ} 10^{\prime} \mathrm{W}$ ). The region is subject to a typical semi-arid climate with an average annual temperature of $27^{\circ} \mathrm{C}$. The animals were isolated from the females for 6 months before the commencement of the study and kept under a $12 \mathrm{~h}$ natural photoperiod. They were maintained outdoors in paddocks $(20 \times 3 \mathrm{~m})$ with a covered area of $(3 \times 3 \mathrm{~m})$ in groups of five. The animals were fed a diet of fruits and sow food, and water was provided ad libitum.

The animals were kept on a $12 \mathrm{~h}$ fast before starting the experiments. They were then physically restrained by means of a hand net and anesthetized by an intravenous administration of propofol (Propovan ${ }^{\circledR}$, Cristalia, Fortaleza, Brazil) at $5 \mathrm{mg} / \mathrm{kg}$ in their bolus (Souza et al. 2009). When the animals showed signs of awakening, then $1 / 4$ of the respective dosage was administered to keep them in an anesthetic state. During the procedure, an indwelling venous catheter was inserted into the cephalic vein for fluid therapy ( $0.9 \%$ physiological saline solution), and the physiologic parameters were monitored.

The animals were kept in lateral recumbence, and the semen samples were collected by using an electroejaculator (Autojac ${ }^{\circledR}$, Neovet, Campinas, SP, Brazil) connected to a 12-V source. The stimulatory cycle comprised of 10 stimuli in each voltage, starting from $5-\mathrm{V}$, followed by voltage increases in steps of $1-\mathrm{V}$ up to $12-\mathrm{V}$. Each electrical stimulus lasted for 3s with intermittent breaks of $2 \mathrm{~s}$. The stimuli were maintained for a duration of $10 \mathrm{~min}$ from the beginning of the procedure (Castelo et al. 2010). The electroejaculator probe measured $15 \mathrm{~cm}$ (length) and $1.3 \mathrm{~cm}$ (diameter); and $12 \mathrm{~cm}$ were inserted into the rectum of the male.

The semen was collected in plastic tubes and immediately evaluated for volume and color. The sperm motility (\%) and vi-

Table 1. Percentage data (mean \pm SEM) for normal sperm and morphological sperm defects of collared peccary (Pecari tajacu) semen $(n=10)$ using different staining methods

\begin{tabular}{lccc}
\hline \multicolumn{1}{c}{ Sperm characteristics (\%) } & \multicolumn{3}{c}{ Staining methods } \\
\cline { 2 - 4 } & Bengal rose & $\begin{array}{c}\text { Bromephe- } \\
\text { nol blue }\end{array}$ & $\begin{array}{c}\text { Eosine- } \\
\text { nigrosine }\end{array}$ \\
\hline Normal sperm & $88.3 \pm 2.6^{\mathrm{a}}$ & $88.4 \pm 1.4^{\mathrm{a}}$ & $89.9 \pm 2.6^{\mathrm{a}}$ \\
Head defects & & & \\
Acrosome defects & $0.2 \pm 0.1^{\mathrm{a}}$ & $0.3 \pm 0.1^{\mathrm{a}}$ & $0.2 \pm 0.1^{\mathrm{a}}$ \\
Detached head & $1.1 \pm 0.4^{\mathrm{a}}$ & $1.7 \pm 0.3^{\mathrm{a}}$ & $2.9 \pm 0.9^{\mathrm{a}}$ \\
Macrocephalic & $0.1 \pm 0.1^{\mathrm{a}}$ & $0.5 \pm 0.3^{\mathrm{a}}$ & $0.4 \pm 0.2^{\mathrm{a}}$ \\
Microcephalic & $0.1 \pm 0.1^{\mathrm{a}}$ & $0.5 \pm 0.2^{\mathrm{a}}$ & $0.1 \pm 0.1^{\mathrm{a}}$ \\
Other head defects & $0^{\mathrm{a}}$ & $0^{\mathrm{a}}$ & $0.2 \pm 0.1^{\mathrm{a}}$ \\
Midpiece and droplet defects & & & \\
Abaxial implantation & $0^{\mathrm{a}}$ & $0.1 \pm 0.1^{\mathrm{a}}$ & $0^{\mathrm{a}}$ \\
Rough/swollen midpiece & $0^{\mathrm{a}}$ & $0.2 \pm 0.1^{\mathrm{a}}$ & $0.1 \pm 0.1^{\mathrm{a}}$ \\
Reflex midpiece & $0.3 \pm 0.2^{\mathrm{a}}$ & $0.6 \pm 0.2^{\mathrm{a}}$ & $0.3 \pm 0.2^{\mathrm{a}}$ \\
Midpiece broken at neck & $0.3 \pm 0.2^{\mathrm{a}}$ & $0.4 \pm 1.2^{\mathrm{a}}$ & $0.3 \pm 0.1^{\mathrm{a}}$ \\
Proximal cytoplasmatic droplet & $0.1 \pm 0.1^{\mathrm{a}}$ & $0^{\mathrm{a}}$ & $0.3 \pm 0.1^{\mathrm{a}}$ \\
$\quad$ Distal cytoplasmatic droplet & $0.2 \pm 0.1^{\mathrm{a}}$ & $0.2 \pm 0.1^{\mathrm{a}}$ & $0.2 \pm 0.1^{\mathrm{a}}$ \\
Tail defects & & & \\
Coiled tail & $1.9 \pm 0.7^{\mathrm{a}}$ & $2.8 \pm 0.6^{\mathrm{a}}$ & $2.8 \pm 0.8^{\mathrm{a}}$ \\
Bent coiled tail & $1.8 \pm 0.6^{\mathrm{a}}$ & $5.3 \pm 1.3^{\mathrm{b}}$ & $2.3 \pm 1.3^{\mathrm{a}}$ \\
Duplicate tail & $1.4 \pm 1.4^{\mathrm{a}}$ & $0^{\mathrm{a}}$ & $0.2 \pm 0.2^{\mathrm{a}}$ \\
Other tail defects & $1.4 \pm 0.8^{\mathrm{a}}$ & $0.3 \pm 0.2^{\mathrm{ab}}$ & $0.2 \pm 0.1^{\mathrm{b}}$ \\
Total defects & $11.7 \pm 2.6^{\mathrm{a}}$ & $11.9 \pm 1.4^{\mathrm{a}}$ & $10.6 \pm 2.5^{\mathrm{a}}$
\end{tabular}

$\overline{a, b}$ Within a row, means without a common superscript differed $(\mathrm{P}<0.05)$. 

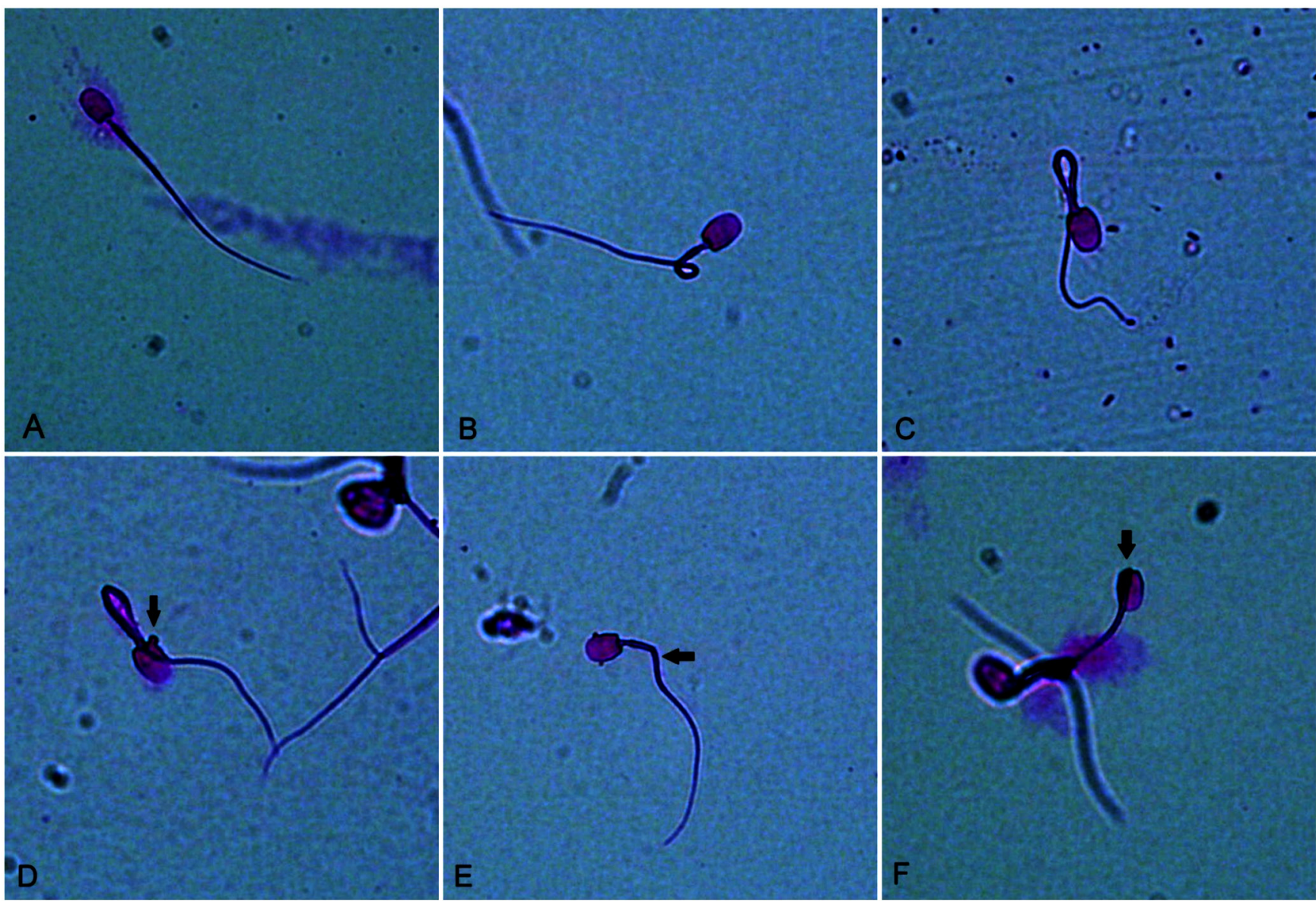

Fig.1. Sperm of collared peccary (Pecari tajacu) stained with Bengal Rose. (A) Normal sperm. (B,C) Bent coiled tail. (D) Abnormal shape of the head. (E) Broken midpiece. (F) Broken neck. Light microscopy, 100x.

gor (0-5) were immediately assessed by using light microscopy under $100 \mathrm{x}$ and 400x magnification. After initial assessment, a semen aliquot $(10 \mu \mathrm{L})$ was diluted in $10 \%$ buffered formalin $(2 \mathrm{~mL})$, and sperm concentration was determined by using a Neubauer counting chamber.

After collection, three semen smears were prepared for each ejaculate by using different staining techniques, and 200 cells were counted through light microscopy (1000x) in five randomly selected fields for each smear. The first smear was stained with Bengal rose (Cromato ${ }^{\circledR}$, SP, Brazil - Castelo et al. 2010); the second smear was stained with brome-phenol blue (Cromoline ${ }^{\circledR}$, SP, Brazil - Toniolli et al. 2010); and the last one was prepared with eosin-nigrosin stain (Sigma-Aldrich ${ }^{\circledR}$, SP, Brazil - Kahwage et al. 2010). Percentages of normal and altered sperm were verified for each smear, and the percentage of acrosome integrity was also analyzed. Morphologic defects were classified according to the region of the sperm, as head, midpiece (including droplets) or tail defects (CBRA 1998). In order to compare the efficiency of the staining methods, scores varying from 3-good, 2-regular, and 1-bad were attributed, according to recommendations of Barth \& Oko (1989) adapted.

Ten ejaculates originated from different animals were used for sperm morphometry. Bengal rose smears were prepared and evaluated. A hundred sperm cells from random fields were captured through light microscopy connected to image analyzer software (Micrometrics SE Premium v.2.8, Princeton, MN). Sperm structures as head, mid-piece, and tail were separately measured.

Statistical analysis. Statistical analyses were carried out by using Statview 5.0 (SAS, Cary, NC, USA). Data for sperm morpho- logical and morphometric evaluation were ArcSin transformed. Sperm morphology and acrosome integrity determined by the different staining methods were compared by variance analysis followed by Student's t Test. Results for staining quality were evaluated by Mann-Whitney test. The results were considered significant when $\mathrm{P}<0.05$.

\section{RESULTS}

Mean $( \pm$ SEM) fresh semen end points $(n=10$ ejaculates originated from 10 different males) were $1.9 \pm 0.2 \mathrm{~mL}$ for volume, with a concentration of $439 \pm 60.3 \times 10^{6}$ sperm/ $\mathrm{mL}, 94 \pm 0.7 \%$ motile sperm presenting vigor $4.6 \pm 0.2$ (Тable 1).

Normal and altered spermatozoa from collared peccary labeled with different staining are presented in Figures 1-3. Percentage values for normal sperm and total defects were similar among staining techniques (Table 1). Detached heads and tail defects were the most frequent sperm abnormality using all the staining techniques. The best visualization of sperm was achieved in the used of Bengal rose staining (Fig.1), since that a higher incidence of bent coiled tails was verified in the use of brome-phenol blue staining $(\mathrm{P}<0.05$, Fig.2), and the use of eosin-nigrosin stain did not allow an adequate impregnation, and some sperm presented a few contrasts with the background (Fig.3).

Scores for staining quality are presented in Table 2. All the staining methods were similarly efficient for the 


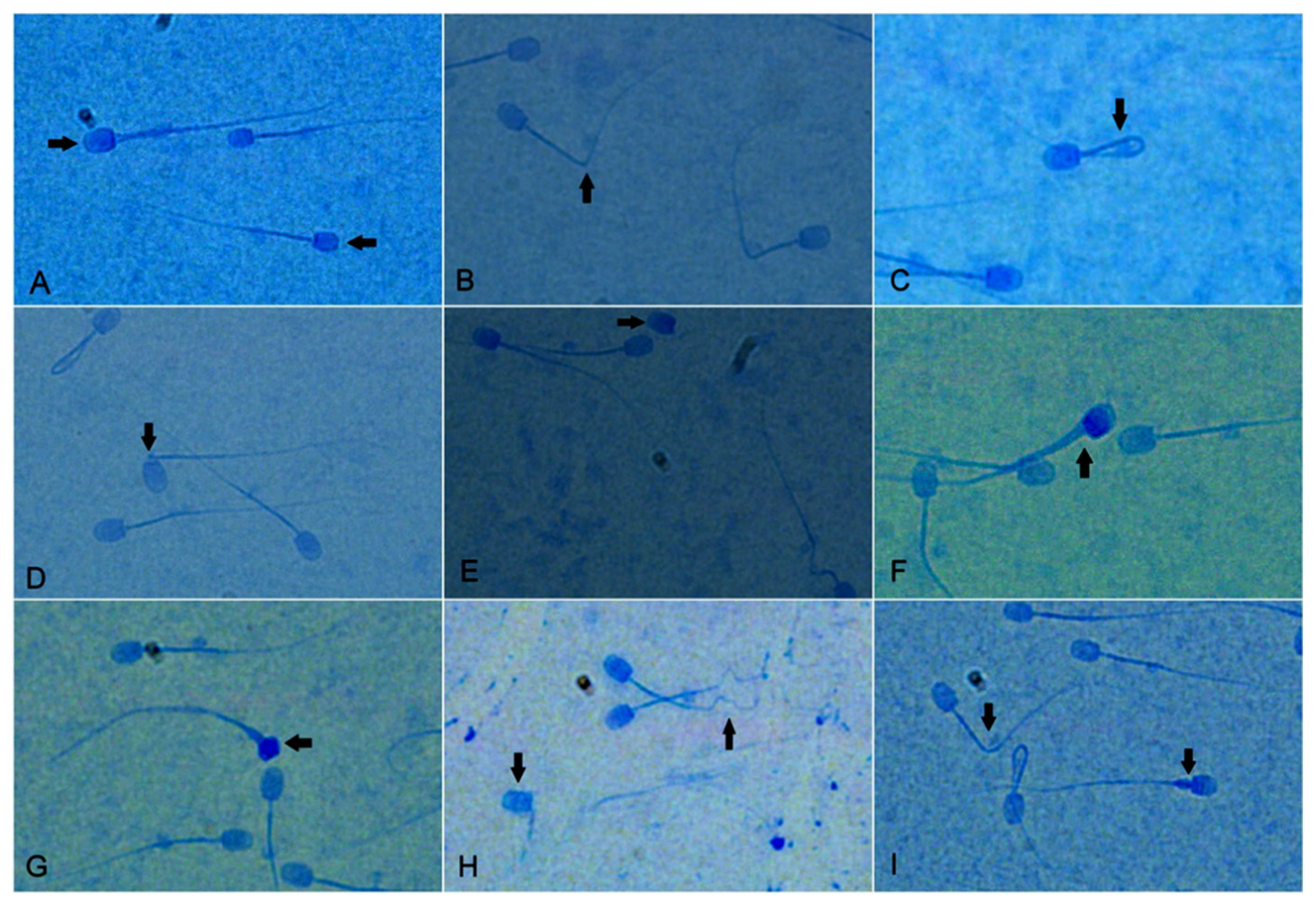

Fig.2. Sperm of collared peccary (Pecari tajacu) stained with brome phenol blue. (A) Macrocephalic (arrow pointing right) and normal sperm (arrow pointing left). (B) Broken tail (arrow). (C) Bent coiled tail (arrow). (D) Broken neck (arrow). (E) Detached head (arrow). (F) Abaxial insertion of the tail and thick midpiece. (G) Abnormal shape of the head. (H) Head prominent (arrow pointing down) and broken tail (arrow pointing up). (I) Folded tail (left arrow) and proximal droplet (right arrow). Light microscopy, 100x.

Fig.3. Sperm of collared peccary (Pecari tajacu) stained with Eosin-Nigrosin. (A) Distal droplet (arrow pointing down) and bent coiled tail (arrow pointing right). (B) Broken tail (arrow pointing right) and normal sperm (arrow pointing up). (C) Proximal (arrow pointing right) and distal droplet (arrow pointing up). (D) Macrocephaly (circle); note the poor visualization of the sperm tails. Light microscopy, 100x.

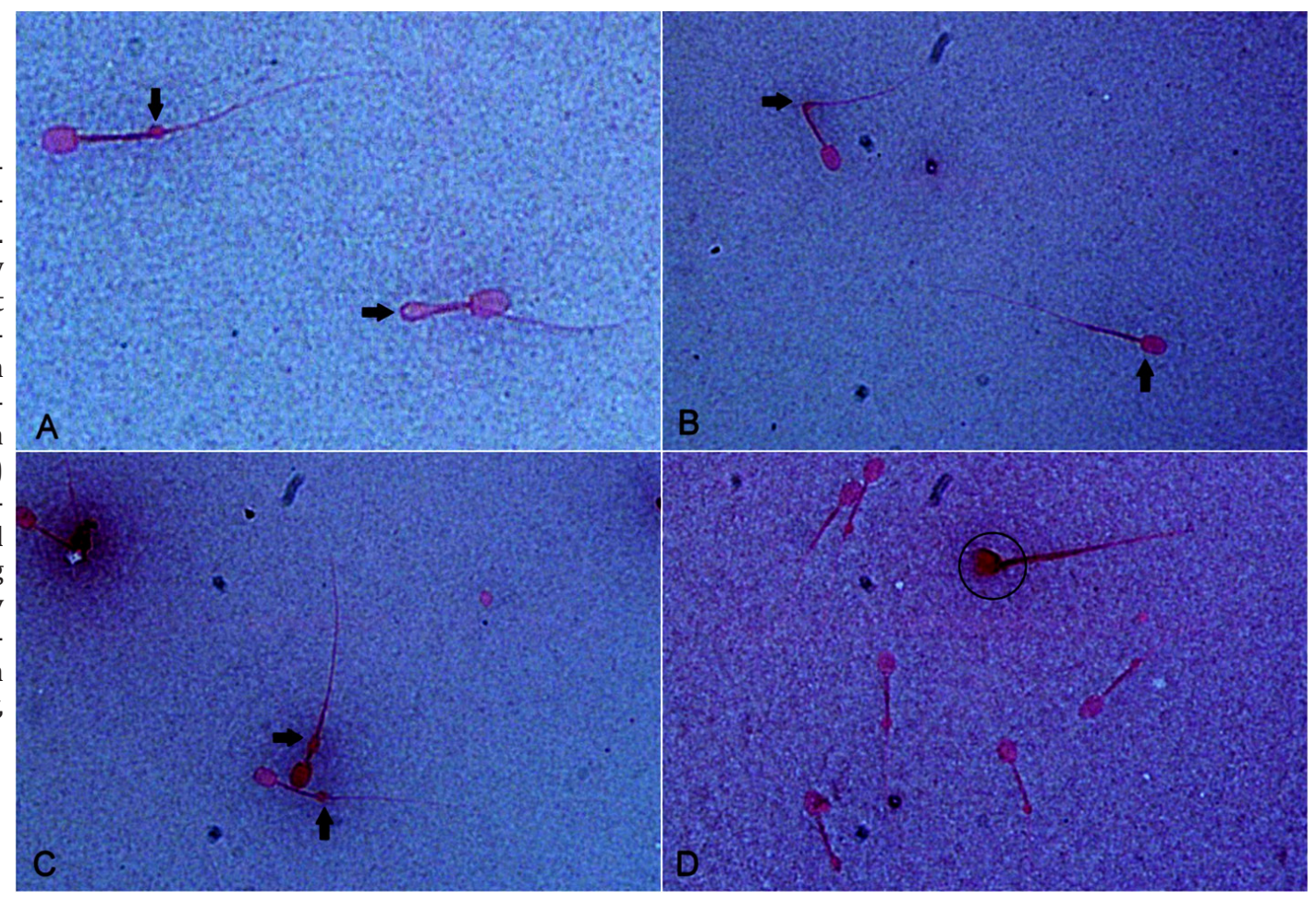

sperm tail analysis $(\mathrm{P}>0.05)$. Eosin-nigrosin stain presented a reduced accuracy for the visualization of other sperm structures $(\mathrm{P}<0.05)$. None of the staining techniques presented higher values for the visualization of the acrosome.

The results for sperm morphologic evaluation showed that sperm heads have a discrete elongate form, with a base thinner than the apex. The tail is inserted on the posterior region of the sperm head by the connection piece or lap. The midpiece is found at the anterior portion of the sperm tail, and presents a distal narrow segment immediately at the transition region to the principal piece. The sperm tail has a conic form, being narrow as it approaches the final portion. Through the sperm morphometric analysis, it was verified that the tail occupies the greatest proportion (89\%) of the sperm (Table 3 ). 
Table 2. Scores (3-good, 2-regular, 1-bad) for staining quality (mean \pm SEM) of different staining methods with regards to the detection of structures of collared peccaries (Pecari tajacu) sperm (n=10 ejaculates)

\begin{tabular}{lccc}
\hline Sperm structure & \multicolumn{3}{c}{ Staining methods } \\
\cline { 2 - 4 } & Bengal rose & Brome phenol blue & Eosin-nigrosin \\
\hline Head & $3 \pm 0^{\mathrm{a}}$ & $2.7 \pm 0.5^{\mathrm{a}}$ & $2.1 \pm 0.6^{\mathrm{b}}$ \\
Acrosome & $1.5 \pm 0.8^{\mathrm{ab}}$ & $1.7 \pm 0.5^{\mathrm{a}}$ & $1.1 \pm 0.3^{\mathrm{b}}$ \\
Mid-piece & $2.1 \pm 0.6^{\mathrm{a}}$ & $2 \pm 0.8^{\mathrm{a}}$ & $1.4 \pm 0.5^{\mathrm{b}}$ \\
Tail & $3 \pm 0^{\mathrm{a}}$ & $2.9 \pm 0.3^{\mathrm{a}}$ & $2.4 \pm 0.9^{\mathrm{a}}$
\end{tabular}

$\overline{a, b}$ Within a row, means without a common superscript differed $(\mathrm{P}<0.05)$.

Table 3. Morphometric percentage data (mean \pm SEM) of sperm from collared peccaries (Pecari tajacu)

\begin{tabular}{lc}
\hline & Mean \pm SEM \\
\hline Head length $(\mu \mathrm{m})$ & $6.34 \pm 0.018$ \\
Head width $(\mu \mathrm{m})$ & $4.20 \pm 0.019$ \\
Midpiece length $(\mu \mathrm{m})$ & $13.29 \pm 0.032$ \\
Tail length $(\mu \mathrm{m})$ & $32.25 \pm 0.076$ \\
Total length $(\mu \mathrm{m})$ & $50.68 \pm 0.121$
\end{tabular}

\section{DISCUSSION}

In order to improve the protocols for sperm morphology analysis, comparisons on staining techniques are currently described for several species. In collared peccaries, present research demonstrate that Bengal rose was more efficient than brome-phenol blue and eosin-nigrosin staining for the evaluation of fresh sperm morphology. Similarly, in the fish Piaractus mesopotamicus, the Bengal rose provide less artifacts addition and a more evident visualization of sperm morphology than the Congo red and Williams-modified staining (Streit-Jr et al. 2004). In cats, neither the Karras-modified nor the Fast Green FCF/Bengal rose staining were totally efficient for detecting sperm defects (Villaverde et al. 2008). In goats, the brome-phenol blue staining is reported to be more efficient than the eosin-nigrosin for the morphological evaluation as in fresh as in frozen-thawed sperm (Oliveira et al. 2009).

In present study, flagellum defects were the sperm alterations more frequently observed, no matter what stain was used; but a significant higher incidence of bent tails was observed in the use of brome-phenol blue. Similar results were verified for goats that brome-phenol blue, in spite of providing a better visualization, promoted a higher percentage of flagellum alterations when compared to eosin-nigrosin staining (Oliveira et al. 2009). In fact, it is hypothesized that the stain preparation or the label technique could favor the occurrence of sperm tail defects (Villaverde et al. 2008). The incidence of the tail defects in sperms could be provoked by fiber disruption (Blom 1966) as a consequence of the osmotic difference between the sperm cell and the solution in which the sample is immersed (Hermann et al. 1994). It is suggested that the use of a fixation solution earlier to the staining procedure might improve the action of a certain stain (Streit-Jr et al. 2004). This fact was also demonstrated in canine (Aguiar et al. 1994) and bovine (Galvani et al. 2000), in which better results were obtained by using formaldehyde-saline solution for dilution and preparation of smears. In this sense, the use of
Bengal rose staining would be more suitable than the other staining techniques due to the presence of formaldehyde, a fixation solution, as a part of its composition.

The sperm tail was easily visualized in the use of all the staining techniques tested. The proximity of the membranes along the tail provides a higher concentration of the stain and consequently, a better visualization. However, the lowest contrast between the sperm and the glass slide background could explain the difficulties found in visualizing the other structures labeled with eosin-nigrosin. This fact was previously verified by Oliveira et al. (2009), who considered the treatment with eosin-nigrosin less efficient than brome-phenol blue stain, especially for visualization of the head defects in caprine sperm.

No matter of the staining technique used; there was a difficulty in the visualization of the acrosome through light microscopy in collared peccaries. In fact, literature reports that acrosome evaluations require a phase-contrast or a differential interference contrast microscopy. Such microscopies allow the identification of distinct acrosome membranes, especially in the species with large acrosome as the guinea-pig (Cross \& Meizel 1989), but also applied for the swine sperm (Pursel \& Johnson 2003). The transmission electron microscopy is another alternative for the evaluation of the acrossomal status in mammals, mainly used for the identification of acrossomal reaction (Cross and Meizel 1989). In addition, the use of the probe isothiocyanate-conjugated peanut agglutinin (FITC-PNA) evaluated under epifluorescence microscopy is recommended for the identification of the acrossomal status in swine (Hu et al. 2009). Based on these statements, we can suggest that other techniques should be tested for the evaluation of acrosome in collared peccary sperm.

Sperm abnormalities have long been associated with male infertility and sterility in most species studied. These abnormalities vary from morphological defects that are evident on clinical examination to those which are more subtly defective (Chenoweth et al. 2005). An understanding of the significance of specific types of sperm abnormalities and the numbers in which these are detected in the ejaculate allows the diagnostician to make a prognosis of fertility and might indicate a course of treatment to assist in the recovery of a male with abnormal sperm production (Freneau et al. 2010). It should be noted that there is currently a substantial amount of support for the recommendation that the minimum percentage of morphologically normal sperm in an ejaculate should lie in the range of $70-80 \%$ in order to achieve optimum fertility (Kuster et al. 2004). The current findings are consistent to the normal range of sperm morphology accepted for other species, since that 80\% normal sperm were verified in the use of all the staining techniques in collared peccaries. However, the values are higher than the 40 (Hellgreen et al. 1989) and 68\% (Kahwage et al. 2010) previously reported for the same species. It is necessary to emphasize that both previous studies collected semen from males that were bred in group together to females. Such males could randomly copulate, which could negatively interfere to the semen quality. In present research, males were kept isolated to females for six months, 
and they were monthly collected for other experiments on semen technology. Furthermore, animals were proved to be healthy before initiating the experiments. This care was essential for the present research since it was previously suggested that degenerative alterations of the testes could negatively affect the sperm morphology in collared peccaries (Costa \& Paula 2005).

As observed for the majority of the mammalian species, the sperm morphometric analysis in collared peccaries reveals that the tail including the midpiece was the longest portion of the sperm, representing $89 \%$ in average. This value is similar to that found for other wild species such as the bear (Ursus americanus) (Brito et al. 2010) and the cavies (Hydrochoerus hydrochaeris) (Batalha et al. 2006). In addition, the sperm of the peccaries presented a discretely elongated sperm head, with values for length and width closer to that previously described for the same species (Meisner et al. 2005). In cavies (Hydrochoerus hydrochaeris), it is suggested that an elongate pattern of sperm head may be related to the evolutive aspect that can take to a spermatic competition inside the female reproductive tract, due to the accepting of the mating by a lot of males (Batalha et al. 2006). However, in free-ranging peccaries, males do not vigorously compete for estrus females, because the alpha male copulates with most of the estrus females in the herd. In penned conditions, females are dominant over males in most situations (Bissonete 1982), and the court is started by the female (Deutsch \& Puglia 1988).

Nevertheless, the head length of sperm in collared peccaries is inferior to that in domestic pigs, which present an average of $8.82 \mu \mathrm{m}$ of length (Villalobos et al. 2008). The existence of a positive correlation between fertility and sperm head morphometry was demonstrated in swine (Villalobos et al. 2008), in which males with high fertility presented values for $8.9 \mu \mathrm{m}$ length and $4.5 \mu \mathrm{m}$ width. In peccaries, the existence of relations between sperm morphometry and fertility remains to be studied.

\section{CONCLUSIONS}

The use of Bengal rose staining is recommended for the morphologic evaluation of the collared peccary sperm through light microscopy.

The morphometry of the entire sperm was for the first time described in this species.

We demonstrated that the tail occupies the greatest proportion of the sperm that presents a discretely elongated head.

Acknowledgements.- To CEMAS/Ufersa for providing the animals used in the experiment.

\section{REFERENCES}

Am-in N., Kirkwood R.N., Techakumphu M. \& Tantasuparuk W. 2011. Lipid profiles of sperm and seminal plasma from boars having normal or low sperm motility. Theriogenology 75:897-903.

Aguiar P.H.P., Costa M.E.L.T., Abreu J.J. \& Abreu C.P. 1994. Coleta e avaliação de sêmen canino. Arq. Bras. Med. Vet. Zootec. 46(5):537-544.

Barth A.D. \& Oko R.J. 1989. Abnormal Morphology of Bovine Spermatozoa. Iowa State University Press, Ames. 285p.
Batalha L.M. \& Oba E. 2006. Caracterização morfométrica e morfológica de célula espermática de capivara (Hydrochoerus hydrochaeris). Archs Vet. Sci. 11:66-72.

Binossete A. 1982. Collared peccary (Dicotyles tajuca), p.841-850. In: Chapman J.A. \& Feldhamer G.A. (Eds), Wild Mammals of North America: biology, management and economics. John Hopkins University Press, Baltimore. 1147p.

Blom E. 1966. A new sterilizing and hereditary defect (the/324Dag defect') located in the bull sperm tail. Nature 209:739-740.

Brito L.F., Sertich C.P.L., Stull G.B., Rives W. \& Knobbe M. 2010. Sperm ultrastructure, morphometry, and abnormal morphology in American black bears (Ursus americanus). Theriogenology 74(8):1403-1413.

Cavalcante-Filho M.F., Miglino M.A., Machado G.V., Bevilacqua E.M.A.F. \& Neves W.C. 1998. Comparative study of the morphology of the stomach of white lipped peccary (Tayassu pecari) and of the collared peccary ( $\mathrm{Ta}$ yassu tajacu ). Braz. J. Morphol. Sci. 15:206-207.

Castelo T.S., Bezerra F.S.B., Lima G.L., Alves H.M., Oliveira I.R.S., Santos E.A.A., Peixoto G.C.X. \& Silva A.R. 2010. Effect of centrifugation and sugar supplementation on the semen cryopreservation of captive collared peccaries (Tayassu tajacu). Cryobiology 61:275-279.

CBRA 1998. Manual para Exame Andrológico e Avaliação de Sêmen Animal. $2^{a}$ ed. Colégio Brasileiro de Reprodução Animal, Belo Horizonte. $49 \mathrm{p}$.

Chenoweth P.J. 2005. Genetic sperm defects. Theriogenology 64:457-468.

Costa G.M.J., Leal M.C., Silva J.V., Ferreira A.C.S., Guimarães D.A. \& França L.R. 2010. Spermatogenic cycle length and sperm production in a feral pig species (Collared Peccary, Tayassu tajacu). J. Androl. 31:221-230.

Costa D.S. \& Paula T.A.R. 2005. Semen collection and evaluation of the collared peccary (Tayassu tajacu). Biota Neotropica 5(2):1-6.

Costa D.S., Henry M. \& Paula T.A.R. 2004. Spermatogenesis of collared peccary (Tayassu tajacu). Arq. Bras. Med. Vet. Zootec. 56(1):46-55.

Costa D.S., Silva J.F. \& Silveira L.S. 2007. Morphometry of Leydig cells in the collared peccary (Tayassu tajacu). Braz. J. Vet. Res. Anim. Sci. 44(5):384389.

Cross N.L. \& Meizel S. 1989. Methods for evaluating the acrossomal status of mammalian sperm. Biol. Reprod. 41:635-641.

Deutsch L.A. \& Puglia L.R.R. 1988. Os Animais Silvestres: proteção, doenças e manejo. Editora Globo, Rio de Janeiro. 191p.

Freneau G.E., Chenoweth P.J., Ellis R. \& Rupp G. 2010. Sperm morphology of beef bulls evaluated by two different methods. Anim. Reprod. Sci. 118(2/4):176-81.

Fridrychová S., Opletal M., Macávoká K., Lustyková A., Rozkot M. \& Lipensky J. 2011. Effects of herbal preparation on libido and semen quality in boars. Reprod. Domest. Anim. 46:573-578.

Gage M.J.G. 1998. Mammalian sperm morphometry. Proc. R. Soc. Lond. 265:97-103.

Galvani F., Costa E.P., Torres C.A.A., Bruschi J.H., Santos M.D. \& Pinheiro R.W. 2000. Perímetro escrotal, características físicas do sêmen e morfopatológicas dos espermatozóides de touros Nelore de alta libido comparados com animais de libidos inferiores. Ars Vet. 16(2):97-103.

Hellgren E.C., Lochmiller R.L., Amoss Jr M.S.S., Seager W.J., Magyar S.J., Coscarelli K.P. \& Grant W.E. 1989. Seasonal variation in serum testosterone, testicular measurements and semen characteristics in the collared peccary (Tayassu tajacu). J. Reprod. Fertil. 85:677-686.

Herman H.A., Mitchell J.R. \& Doak G.A. 1994. Evaluation of semen-morphology, p.87-92. In: Herman H.A., Mitchell J.R. \& Doak G.A. (Eds), The Artificial Insemination and Embryo Transfer of Dairy and Beef Cattle. $8^{\text {th }}$ ed. Interstate Publishers, Dauville.

Hidalgo M., Rodriguez I., Dorado J., Sanz J. \& Soler C. 2005. Effect of sample size and staining methods on stallion sperm morphometry by the Sperm Class Analyzer. Vet. Med. 50(1):24-32.

Hu J.H., Li Q.W., Li G., Jiang Z.L., Bu S.H., Yang H. \& Wang L.Q. 2009. The cryoprotective effect of trehalose supplementation on boar sperm quality. Anim. Reprod. Sci. 112(1/2):107-118.

Immler S., Pryke S.R., Birkhead T.R. \& Griffith S.C. 2010. Pronounced with- 
in-individual plasticity in sperm morphometry across social environments. Evolution 64(6):1634-1643.

Kahwage P.R., Garcia A.R., Guimarães D.A.A., Ohashi O.M., Luz-Ramos R.S., Dias H.L.T., Albuquerque N.I. \& Bartha M.M.P. 2010. Biometria testicular, eletroejaculação e características seminais de caititus, Tayassu tajacu Linnaeus, 1758 (Mammalia, Artiodactyla, Tayassuidae) mantidos em cativeiro na Amazônia Oriental. Acta Amazônica 40(4):771-778.

Kim S., Lee Y.J. \& Kim Y.J. 2011. Changes in sperm membrane and ROS following cryopreservation of liquid boar semen stored at $15^{\circ} \mathrm{C}$. Anim. Reprod. Sci. 124(1/2):118-124.

Kuster C.E., Singer R.S. \& Althouse G.C. 2004. Determining sample size for the morphological assessment of sperm. Theriogenology 61(4):691-703.

Mayor P., Galvez H., Guimarães D.A., López-Gatius F. \& López-Béjar M. 2007. Serum estradiol-17beta, vaginal cytology and vulvar appearance as predictors of estrus cyclicity in the female collared peccary (Tayassu tajacu) from the eastern Amazon region. Anim. Reprod. Sci. 97(1/2):165-174.

Meisner A.D., Klaus A.V. \& O'Leary M.A. 2005. Sperm head morphology in 36 species of artiodactylans, perissodactylans, and cetaceans (Mammalia). J. Morphol. 263:179-202.

Moraes E.A., Torres C.A.A., Guimarães J.D. \& Murgas L.D.S. 2010. Effect of oil sources and vitamin E supplementation in the diet on physical and morphological characteristics of fresh boar semen. Arq. Bras. Med. Vet. Zootec. 62(3):521-527.

Oliveira R.V., Nunes J.F., Salgueiro C.C.M., Cavalcante J.M.M., Moura A.A.A.M. \& Araújo A.A. 2009. Avaliação morfológica de espermatozoides caprinos diluídos e congelados em meio à base de água de coco em pó (ACP101) ou TRIS, corados por eosina-nigrosina e azul de bromofenol. Ciênc. Anim. Bras. 10(3):862-869.
Phillips N.J., McGowan M.R., Johnston S.D. \& Mayer D.G. 2004. Relationship between thirty post-thaw spermatozoal characteristics and the field fertility of 11 high-use Australian dairy AI-sires. Anim. Reprod. Sci. 81(1/2):47-61.

Pursel V.G. \& Johnson L.A. 1974. Glutaraldehyde fixation of boar spermatozoa for acrosome evaluation. Theriogenology 1(2):63-68.

Rodríguez-Martínez H. 2007. State of the art in farm animal sperm evaluation. Reprod. Fertil. Dev. 19(1):91-101.

Souza A.L.P., Castelo T.S., Queiroz J.P.A.F., Barros I.O., Paula V.V., Oliveira M.F. \& Silva A.R. 2009. Evaluation of anesthetic protocol for the collection of semen from captive collared peccaries (Tayassu tajacu) by electroejaculation. Anim. Reprod. Sci. 116(3/4):370-375.

Streit-Jr D.P., Moraes G.V., Ribeiro R.P., Povh J.A., Souza E.D. \& Oliveira C.A.L. 2004. Avaliação de diferentes técnicas para coloração de sêmen de peixes. Arq. Ciênc. Vet. Zool. 7(2):157-162.

Toniolli R., Toniollo G., Franceschini P.H. \& Morato F.M.A.C. 2010. Use of powder coconut water as extender (ACP-103 ${ }^{\circledR}$ ) for boar semen longer preservation: in vitro and in vivo evaluations. Arq. Bras. Med. Vet. Zootec. 62(5):1072-1079.

Villalobos D.G., Quintero-Moreno A., López-Brea J.J.G., Esteso M.C., Fernández-Santos M.R., Rubio-Guillén J., Silva W.M., Marval Y.G., Atencio G.L. \& Bohórquez C.L. 2008. Caracterización morfométrica de la cabeza del espermatozoide porcino mediante análisis computarizado (Resultados Preliminares). Revta Cient. FCV-LUZ 18(5):570-577.

Villaverde A.I.S.B., Melo C.M., Corrente J.E., Papa F.O. \& Lopes M.D. 2008. Comparação entre dois métodos de coloração para análise morfológica e acrossomal de espermatozoides de gato doméstico (Felis catus). Ciênc. Anim. Bras. 9(3):686-692. 